\title{
Robert O. Keohane: The Study of International Relations*
}

\author{
Peter A. Gourevitch, University of California, San Diego
}

\begin{abstract}
In electing Robert Keohane APSA president, members have made an interesting intellectual statement about the study of international relations. Keohane has been the major theoretical challenger in the past quarter century of a previous Association president, Kenneth Waltz, whose work dominated the debates in the field for many years. Keohane's writings, his debate with Waltz, his ideas about institutions, cooperation under anarchy, transnational relations, complex interdependence, ideas, and domestic politics now stand as fundamental reference points for current discussions in this field. ${ }^{1}$

Theorizing, methodology, extension, and integration: these nouns make a start of characterizing the contributions Robert Keohane has made to the study of international relations.

Theorizing - Keohane challenges the realist analysis that anarchy and the security dilemma inevitably lead states into conflict, first with the concept of transnational relations, which undermines the centrality of the state as the unit of analysis, then with neoliberal institutionalism, which argues that even if the state is a unitary actor, institutions can overcome the obstacles to cooperation that arise from anarchy.
\end{abstract}

Pefer A. Gourevitch, professor of political science at University of California, San Diego, has published extensively in the field of international political economy and comparative politics. His books include Politics in Hard Times: Comparative Responses to Economic Crises (1986) and The Pacific Rim: Challenges to Policy and Theory (1989). He was a member of the APSA Council from 1990 to 1992 . In 1994, he was elected to the American Academy of Arts and Sciences.

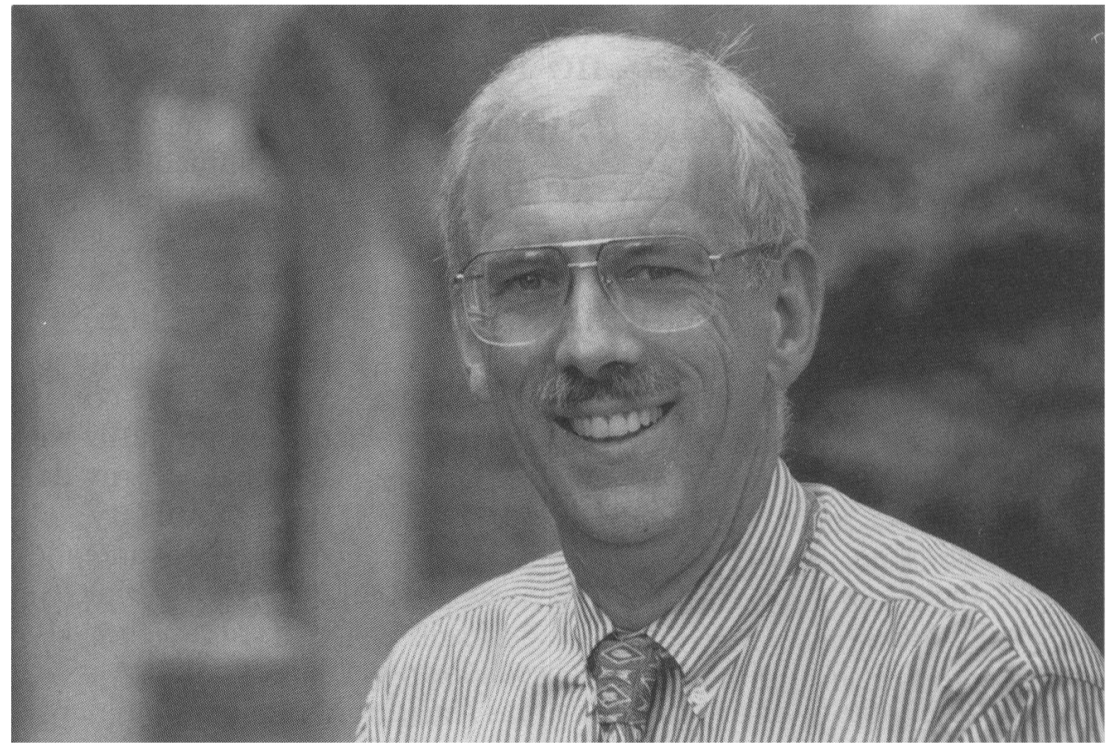

Robert $O$. Keohane

Methodology - Keohane places the study of the strategic interaction among states onto the foundations of economics, game theory, and methodological individualism and encourages the application of positivist techniques of testing and verification.

Extension-Keohane broadens the subject matter of world politics by promoting the field of international political economy as an issue area (the formation of economic policy), as an influence on state behavior (the impact of economic interests within and between states), and as a type of reasoning (especially microeconomics).

Integration-Through his theorizing, methodology, and extension, Keohane helps merge the study of international relations with the discipline of political science by insisting that it can use the same concepts, techniques, and approaches as the broader discpline.

The field of international relations has been quite transformed between the early 1960s, when Keohane entered it, and the late 1990s, when his contributions to that field are being recognized.

Keohane's influence is not diachronic, but a chronological account of his career helps place the development of his ideas in the context of the battles he fought at the time they occurred. Keohane is perhaps most well known for his insistence that institutions shape behavior in important ways. This interest in institutions is readily apparent in his earliest publications, a series of $I n$ ternational Organization articles on the General Assembly of UN (1967, 1969a, 1969b, 1969c), which were related to the work he did for his Ph.D at Harvard, where he went after graduating summa cum laude from Shimer College (IL) in 1961. 
During the early 1970 s, Keohane began to develop the field of international political economy. This marked a major break and innovation, for the field had been dominated by security studies and a hierarchy of importance in which economic goals and influences on policy were less significant than military goals and influences.

Turning to economic policy, Keohane saw that this arena involved the interaction of political actors within states in behaviors that cut across states. The unitary actor model of international relations, or "realism," that dominated the field at that time had no good way of accounting for these influences and relationships.

In place of the unitary actor-realist model, Keohane, writing with his Harvard colleague Joseph Nye, proposed a model in which nations conducted "transnational relations." Oil firms, coffee growers, airlines, banks-all of these involve firms, associations, and interest groups that have a massive impact upon the issue area involved. National governments are players in a policy arena, but their control is by no means exclusive or total. Prices and market shares may be shaped by forces of which governments have little control and each influences what governments do. Two Keohane-Nye publications were especially influential statements of these themes: "Transgovernmental Relations and International Organizations" (1974a) and Transnational Relations and World Politics (1972a).

Continuing to question the unitary state, Keohane and Nye developed the concept of "complex interdependence." Countries deal with multiple issue areas-economics, environment, migration, and culture, to name but a few. In each of these areas, there may be more than one dimensionoil, cars, finance-each with its spe- cific patterns of power and influence. The definition of country interests, the influences on countries from actors within them, and the way countries interact flows through a network of relationships only some of which pass through the formal institutions of the nation-state. Some of these networks are embodied in formal institutions at the international level, like IMF or IATA, but most are not, being comprised of very influential patterns of norms or relationships, which John Ruggie called "regimes." Instead of interactions among unitary states concerned primarily with national security defined in military terms, Keohane and Nye saw multiple issue areas, the breakdown of hierachy among issue areas (military no longer dominant), the declining utility of force, the importance of international regimes and the fragmentation of authority in each state. Instead of international "relations," Keohane and Nye saw international "interactions." The major statement of these themes was pubished as Power and Interdependence (1977a).

During the 1970s, Keohane worked to restructure the institutions articulating the field of international relations itself. Specifically, he became editor of International Organization and transformed it. When Keohane took over, $I O$ was a general-interest journal for students of international institutions. Its articles were a mixture of topical research, description, and opinion. Keohane shifted the focus toward social science research articles based on sound methodology and capable of verification. $\mathrm{He}$ also instituted a stiff peer-review process with the help of a team of university-based faculty from several disciplines. Under his editorship, $I O$ became the leading journal of international political economy, and one of the major research journals in the field of international relations in general. Subsequent editors Peter Katzenstein and Steven Krasner substantially broadened its base of contributors, circulation, and editorial board members, but that is another story. $I O$ as we know it today took shape under the leadership of Keohane.

In the 1970s, Keohane published a number of papers and book chapters in political economy, dealing with topics such as inflation, energy, multinational corporations, trade, and tariffs. Throughout this work, one can see concern with institutions, transnational politics, and domestic politics. In retrospect, one can identify in work done during Keohane's "complex interdependence" phase a number of diverse themes that could lead in different directions. The concept itself was complex: It served as no less than the foundation for a new subfield, international political economy, and a serious alternative to realist thinking in international relations.

Keohane's work emerged in an intellectual milieu in which several challenges to realism were surfacing. One strand of critique questioned unitary actor assumptions by stressing the importance of domestic politics (parties, interest groups and domestic political institutions) in shaping state behavior. Another strand stressed international society or networks that cut across state boundaries. A third considered the influence of culture and ideas. Complex interdependence and transnational relations were composite concepts that contained several elements of these challenges to realism, and which could be taken in different directions. Keohane, and the field, faced some important choices about where to go.

Keohane's choice had very significant consequences for the field. While he has returned to examine ideas and domestic politics in recent years, in the late 1970s Keohane decided to confront head-on the core assumption of realism: the way actors behave in a condition of anarchy. That is, while other challengers of realism sought to devalue the role a "system" plays in determining the behavior of the system's constituents, Keohane wanted to reformulate scholars' understanding of the 
system itself. He set aside the controversy over unitary actors and domestic influences to refashion how we think about actors altogether. In so doing, he focussed his energy on the work of Kenneth Waltz. Waltz had just published his major theoretical statement, Theory of International Politics (1979), which laid out in a very careful way the core premises of realist thinking: the primacy of system in shaping the behavior of the units in it, the constituent elements of a system, and the logic of action in anarchy that leads nations into conflict, however pacific their initial intentions. As most realists before him, Waltz saw conflict as the inevitable outcome of "self-help" actions states take in defense of their national interests.

In challenging Waltz, Keohane accepted the importance of system in shaping state behavior. Where Waltz saw conflict, however, Keohane saw the possibility of cooperation. That cooperation produces benefits superior to conflict has not been challenged by different system theorists; the collective gains from coordination outweigh the solo benefits of conflict. The divergence has always been over whether cooperation will occur. Under the right conditions, Keohane argued, units can devise strategies of cooperation even in the absence of a strong sovereign to punish defectors. Keohane turned to economics, the work on institutions associated with Coase and Williamson, to game theory, and to work of theorists of strategic interaction like Schelling and Axelrod, all of which examine carefully how actors behave in different structurally defined situations in the absence of external authority and direct communication. This work showed that under the right conditions, cooperation could be a productive strategy.

Keohane showed that cooperation often fails because of coordination problems. Actors lack information about the behavior of others and find it costly to obtain such information. Building a positive argument, Keohane argued that institutions can ease these problems: they can share information, reduce transaction costs, provide incentives to trade concessions, provide mechanisms for dispute resolution, and supply processes for making decisions. Institutions can increase cooperation even when no coercive power exists. Institutions may increase iteration, that is the number of interactions among units. This further encourages cooperation, because the more actors are able to observe each other, the more they are able to assess the willingness of the other to comply with cooperative agreements. In these ways, institutions are able to encourage cooperation under anarchy. Keohane showed conflict to be a pole on a continuum, not an inevitable outcome.

By international institutions, Keohane does not mean a government, with a police, army, and courts to punish. Rather, he means a type of organization, formal or informal, to which nations belong because they want to, because they see the benefit of cooperation and seek to overcome the obstacles to collective action that inhibit collaborative action (Keohane and Martin 1995a). From GATT and the WTO to the European Union, to agreements on airlines, the mails, and the environment, a vast network of cooperative arrangements have arisen that fall between the rubric of nation-state and international super-state. These arrangements and the cooperation among them are not captured by traditional models of international relations. Their existence is the key dependent variable for Keohane and his account the major explanation of their existence and efficacy.

After Hegemony (1984a), Keohane's major work in this branch of research, argues that the erosion of
U.S. hegemony (e.g., the fall from $50 \%$ of world GNP to $20 \%$, the emergence of other economic and military poles) would not lead inevitability to conflict, as the realist theorists expected. The international institutions created during hegemony could, Keohane argued, persist and grow. They provided solutions to problems of cooperation and, thereby provided benefits in trade, economic growth, and security. Because of those benefits, these institutions would not easily be threatened or dismantled by those who wanted them to continue. Thus, cooperation could take place even without a dominant power, or hegemon, to solve all the collective action problems. Some have read Keohane as making a modified realist argument here: Hegemony created institutions capable of persisting after the hegemon declines. Keohane actually saw the institutions as more powerful than that. Even without a hegemon as first mover, nations can form institutions able to provide the foundations for cooperative behavior. That current institutions did arise during American hegemony was a historical fact that may have some important influence on their creation and persistence but, at least theoretically, such institutions can come into being without such a leader.

Keohane's book and an edited volume titled Neorealism and Its Critics (1986) quickly became canonical statements in international relations. The quarrel between Keohane and Waltz defined the debate over how to understand "system" in international relations for over a decade. Students engaged in, often heated, discussions of NLI (neoliberal institutionalism ) vs. Realism. Dissertations and papers detailing institutions and how they operated flowed.

This quarrel also defined the battle lines of criticism in the field. Three lines of inquiry may be noted as challenges to the centrality of the Keohane-Waltz debate. First, the domestic politics school, whose members generally were sympathetic to Keohane's critique of Waltz, complained that by moving the debate toward system arguments-cooperation vs. conflict by unitary states under anarchy-the domestic politics 
elements of international politics were being neglected. These writers wanted to continue the disaggregation of the unitary state, which Keohane had begun in the 70 s, by exploring how domestic politics shapes states' perception of their position in the world. Position in the international system was open to rival interpretations. Conflicts occurred within countries over national interests, threats, goals, objectives. The resolution of these quarrels turns on domestic politics, where domestic interest groups, institutions, parties, ideas, and culture can all play a role. Keohane notes countries can cooperate if they want to. For these critics, the issue of whether they want to cooperate turns on domestic politics, on whether there is support at home for cooperation, and whether the supporters are able to prevail in policy debates.

Scholars in the second school, constructivists and sociological theorists, complained that both Keohane and Waltz neglected nonrationalist and nonmaterial aspects of the interaction of units. Keohane accepted, after all, Waltz's assumptions that states were utility maximizers; what he disputed was what maximization under anarchy led to. But neither one paid much attention to culture, ideas, values, the internalization of norms, the constitutive elements of identity, or the tissue of human exchanges and cultures that structure interaction. Some constructivists stayed at the system level and offered a model of the strategic interaction of unitary states being shaped by the cultural and cognitive understandings each internalized from a global system of cultural construction. Other constructivists developed an understanding of culture as a part of domestic politics, and processes, an element in the way people within countries interpret the world.

A third school, consisting largely of security specialists, attacked Keohane's stress on institutions, on the way these operate, and on the neglect of security issues, generally, and in relation to the functioning of institutions, specifically. Some specialists in this camp are realists who agree rather more with Waltz, while others disagree on agenda, the eval- uation of interests, the actual prospects for cooperation, and the implications for public policy.

Keohane has engaged energetically in these debates, vigorously arguing the importance of institutions and their impact on behavior. At the same time, he has, in the $90 \mathrm{~s}$, turned to some of the themes raised in these critiques, or more precisely, returned to them. Many of these issues had been part of his agenda on transnational relations and complex interdependence, which he laid aside in the 80s to focus on the important quarrel over how to understand the nature of the international system. Now, all the while continuing a major focus on institutions, Keohane explores several dimensions of politics toward which a careful understanding of institutions must lead. With Judy Goldstein, Keohane considers how ideas shape foreign policy, within countries, in domestic politics, and between states (Ideas and Foreign Policy 1993a). In Internationalization and Domestic Politics (1996a), Keohane, with Helen Milner, integrates the issue of international institutions with domestic political support. As argued in this book, countries seek cooperation if there is political support at home to do so. They invest in institutions if domestic actors seek gains from doing so, and institutions are strong if the actors support the gains to be obtained.

Keohane has continued the interest in applied policy cases that marked his earliest research on the economy, trade, and resources. Books edited with Peter Haas and Marc Levy (1993b), with Elinor Ostrom (1994b), and again with Marc Levy (1996b) explore international environmental policy, examining the obstacles to collective action in an issue area that requires it and how institutions can deal with these problems. Works on Europe, edited with Stanley Hoffman (1991) and Hoffman and Nye (1993c) study the impact of changing U.S.-Soviet relations on Europe, the world's densest arena of international institutions. A recent volume edited with Helga Haftendorn and Celeste Wallander (1999a) looks at security relations, seeking to link together two historically separate currents of research, reasoning based on political economy and the security studies tradition. A current project with Judy Goldstein, Miles Kahler, and AnneMarie Slaughter examines the boundary between politics and law to understand what processes lead to the legalization of disputes management and what processes push toward political mechanisms. Evident in much of Keohane's writing is a special interest in U.S. foreign policy, from the beginnings of the nation to the present.

Throughout his career, Keohane has sustained an interest in problems of methodology and the linkage between international relations and the study of politics more broadly. With Gary King and Sidney Verba, he published Scientific Inference in Qualitative Research (1994a). This quickly became a major statement of positivist ideas in the field, arguing as it does for integrating the subject matters of international relations with methodologies used in other fields of the discipline. Immediately placed on reading lists of all kinds, this book has become another touchstone in the field, defining controversies over methodology particularly in areas where there are often a limited number of cases (World Wars, for example), and substantial interest in process (how certain decisions were made).

Having helped transform the field of international relations, Keohane accepted an invitation to join his successors at International Organization in editing a 50th anniversary issue of that journal. The editors' coauthored introduction provides a comprehensive statement of their view of the evolution of the field over the past decades, and the articles provide analyses of major issues and concepts (1998c, 1999b).

In addition to his editorial work, Keohane has promoted the development of ideas in a variety of other ways. He has encouraged the work of younger scholars through coauthoring and mentoring. His advisees, who include Vinod Aggarwal, Jon Aronson, Terry Karl, Lisa Martin, Tim McKeown, Helen Milner, Andrew Moravsick, Beth Simmons, David Yoffee, and Fareed Zakaria, have moved successfully through university ranks. 
Married to a very prominent professional woman, Nannerl Keohane, the current president of Duke University, the former president of Wellesley College, a past professor at Stanford and Swarthmore, and a specialist in political theory, Robert has sought to encourage the advancement of women in the field. He has moved several times to assist his wife's career: from Stanford to Brandeis, then from Harvard to Duke. Keohane's first teaching job was at Swarthmore. In 1997, he received the first Mentorship Award from the Society for Women in International Political Economy.

\section{Notes}

\footnotetext{
* Thanks for comments on an earlier draft to David Lake and Lisa Martin.

1. Indeed, the nomination of Robert Jervis to follow Keohane marks another intriguing step in the evolution of this field, for Jervis,
}

Keohane's list of honors is long: president of the International Studies Association; winner of the 1989 Grawemeyer Award for Ideas Improving World Order; recipient of fellowships from the Guggenheim Foundation, the Center for Advanced Study at Stanford, the Social Science Research Council, the German Marshall Fund, and the Council on Foreign Relations.

"Reason is the servant of the passions," wrote David Hume. Perhaps, but energy is the motor of accomplishment. Keohane is a most energetic individual. The fields of international relations, in particular, and political science, in general, have been transformed by his accomplishments. For three decades, he has defined the issues of debate, the concepts, and the vocabulary ("transnational relations," "complex interdependence," "neoliberal institutionalism," "cooperation under anarchy," "the politics of international environmental policy," ideas and domestic politics in international relations, and methodology of political inquiry). His concepts have entered our language. Agree or disagree, no one writes in this field without reference to Keohane's ideas. while close in some ways to the rationalism of both Waltz and Keohane, has pioneered a line of reasoning neither of them has explored-the impact of perception and the characteristics of human cognition and information processing in shaping decision-making and events, but that will be the subject of next year's essay on the president!

\section{Selected Publications}

1999a. Imperfect Unions: Security Institutions Across Time and Space, edited with Helga Haftendorn and Celeste A. Wailander. Oxford: Oxford University Press.

1999b. Exploration and Contestation in the Study of World Politics, edited with Peter J. Katzenstein and Stephen D. Krasner. Cambridge, MA: MIT Press. (Also appeared as a special issue of International Organization.)

1999c. "Ideology and Professionalism in International Institutions: Insights from the Work of Douglas C. North." In Taking Economics Seriously: A Conversation between Nobelist Economists and Political Scientists, ed. James Alt, Margaret Levi, and Elinor Ostrom. New York: Russell Sage.

1998a. "Beyond Dichotomy: Conversations between International Relations and Feminist Theory." International Studies Quarterly 32(March): 193-98.

1998b. "International Institutions: Can Interdependence Work?" Foreign Policy 110(Spring): 8296.

1998c. "International Organization and the Study of World Politics," with Peter J. Katzenstein and Stephen D. Krasner. International Organization 52(Fall).

1998d. "Power and Interdependence in the Information Age," with Joseph S. Nye. Foreign Affairs 77(September-October): $81-95$.

1998e. "When Does International Law Come Home?" Houston Law Review 35(Fall): 699-713.

1997a. "International Relations and International Law: Two Optics." Harvard International Law Journal 38(Spring). 1997b. "Problematic Lucidity: Stephen Krasner's 'State Power and the Structure of Foreign Trade." World Politics 50(October).

1996a. Internationalization and Domestic Politics, edited with Helen V. Milner. Cambridge: Cambridge University Press.

1996b. Institutions for Environmental Aid: Pitfalls and Promise, edited with Marc A. Levy. Cambridge, MA: MIT Press.

1996c. "Lessons for Environmental Aid: Politics, Lessons, and Opportunities," with Barbara Connolly. Environment 38(June).

1995a. "The Promise of Institutionalist Theory," with Lisa L. Martin. International Security 20(Summer): 34-46.

1995b. "An Institutional Approach to Alliance Theory," with Celeste A. Wallander. CFIA Working Paper, Spring.

1994a. Scientific Inference in Qualitative Research, with Gary King and Sydney Verba. Princeton: Princeton University Press.

1994b. Local Commons to Global Interdependence, edited with Elinor Ostrom. Thousand Oaks, CA: Sage Publishers.

1993a. Ideas and Foreign Policy, edited with Judith Goldstein. Ithaca: Cornell University Press.

1993b. Institutions for the Earth: Sources of Effective International Environmental Protection, edited with Peter M. Haas and Marc A. Levy. Cambridge, MA: MIT Press

1993c. After the Cold War: State Strategies and International Institutions in Europe. 1989 1991, edited with Joseph S. Nye and Stanley Hoffman. Cambridge, MA: Harvard University Press.

1993d. "The Analysis of International Re- gimes: Towards a European-American Research Programme." In Regime Theory and International Relations, ed. Volker Rittberger. Oxford: Clarendon Press.

1993e. "Institutionalist Theory and the Realist Challenge after the Cold War." In Neorealism and Neoliberalism: The Contemporary Debate, ed. David Baldwin. New York: Columbia University Press.

1993f. "Sovereignty, Interdependence, and International Institutions." In Ideas and Ideals: Essays on Politics in Honor of Stanley Hoffrnann, ed. Linda B. Miller and Michael Smith. Boulder: Westview Press.

1993g. "The Diplomacy of Structural Change: State Strategies and Multilateral Institutions." In Diplomacy, Force and Leadership: Essays in Honor of Alexander L. George, ed. Dan Caldwell and Timothy J. McKeown. Boulder: Westview.

1991. The New European Community: Decision-Making and Institutional Change, edited with Stanley Hoffmann. Boulder: Westview.

1990a. "International Liberalism Reconsidered." In The Economic Limits to Modern Politics, ed. John Dunn. Cambridge: Cambridge University Press.

1990b. "Multilateralism: An Agenda for Research." International Journal 45(Fall): 731-64.

1989a. International Institutions and State Power: Essays in International Relations Theory. Boulder: Westview.

1989b. "Closing the Fairness-Practice Gap." Ethics and International Affairs 3(April): 101-16.

1989c. "The Rhetoric of Economics as Viewed by a Student of Politics." In The 
Consequences of Economic Rhetoric, ed. Arjo Klamer, Robert McCloskey, and Robert Solow. Cambridge: Cambridge University Press.

1989d. "International Relations Theory: Contributions of a Feminist Standpoint." Millennium: Joumal of International Studies 18(Summer): 245-53.

1988. "International Institutions: Two Approaches." International Studies Quarterly 32(December): 379-96.

1987a. "Power and Interdependence Reconsidered," with Joseph S. Nye Jr. International Organization 41(Fall).

1987b. "The Dynamics of Negotiated Protectionism," with Vinod K. Aggarwal and David B. Yoffie. American Political Science Review 81(June): 345-66.

1986a. Neorealism and Its Critics, ed. New York: Columbia University Press.

1986b. "Reciprocity in International Relations." International Organization 40(Winter).

1985a. "Achieving Cooperation under Anarchy: Strategies and Institutions," with Robert Axelrod. World Politics 38(October): $226-54$.

1985b. "The International Politics of Inflation." In The Politics of Inflation and Economic Stagnation, ed. Charles Maier and Leon Lindberg. Washington, DC: The Brookings Institution Press.

1985c. "Two Cheers for Multilateralism," with Joseph S. Nye Jr. Foreign Policy 60(September): 148-67.

1984a. After Hegemony: Cooperation and Discord in the World Political Economy. Princeton: Princeton University Press. (Japanese edition, 1998.)

1984b. "The World Political Economy and the Crisis of Embedded Liberalism." In Order and Conflict in Contemporary Capitalism: Studies in the Political Economy of Western European Nations, ed. John Goldthorpe. New York: Oxford University Press, for the Social Science Research Council.

1984c. "Theory of World Politics: Structural Realism and Beyond." In Political Science: The State of the Discipline, ed. Ada W. Finifter. Washington, DC: American Political Science Association.

1983a. "Associative American Development, 1776-1860: Economic Growth and Political Disintegration." In The Antinomies of Interdependence, ed. John Gerard Ruggie. New York: Columbia University Press.

1983b. "Perspective: Political Threats to the International Economic System.” In Managing International Risk, ed. Richard J. Herring. New York: Cambridge University Press. 1982a. "The Demand for International Regimes. "International Organization 36 (Spring).

1982b. "International Agencies and the Art of the Possible: The Case of the IEA." Journal of Policy Analysis and Management 1 (June).

1982c. "State Power and Industry Influence: American Oil Policy in the 1940s." International Organization 36(Winter).

1981. "Responding to the 'New Protectionism': Strategies for the Advanced Developing Countries in the Pacific Basin," with David B. Yoffie. In Trade and Growth of the Advanced Developing Countries in the Pacific Basin, ed. Wontack Hong and Lawrence Krause. Seoul: Korean Development Institute.

1980a. "New Trends in International Politics and Economics." In Southeast Asia in a Changing World, ed. Shigekazu Matsumoto. Tokyo: Institute of Developing Economies.

1980b. "The Theory of Hegemonic Stability and Changes in International Economic Regimes, 1967-1977." In Change in the International System, ed. Ole Holsti, Randolph Siverson, and Alexander L. George. Boulder: Westview.

1980c. "The Concept of the National Interest: Uses and Limitations," with Alexander L. George. In Presidential Decisionmaking in Foreign Policy: The Effective Uses of Information and Advice, ed. Alexander L. George. Boulder: Westview.

1979. "United States Foreign Economic Policy Toward Other Advanced Capitalist States: The Struggle to Make Others Adjust." In Eagle Entangled: Contemporary Issues in American Foreign Policy, ed. Kenneth Oye, Donald Rothchild, and Robert J. Lieber. New York: Longman's

1978a. "American Policy and the TradeGrowth Struggle." International Security 3(Autumn).

1978b. "Economics, Inflation and the Role of the State: Political Implications of the McCracken Report." World Politics 31(October).

1978c. "The International Energy Agency: State Influence and Transgovernmental Politics." International Organization 32(Autumn).

1977. Power and Interdependence: World Politics in Transition, with Joseph S. Nye Jr. Boston: Little, Brown. (2nd ed., 1989.)

1976. “Not 'Innocents Abroad': U.S. Multinational Corporations and the U.S. Government." Comparative Politics, January.

1975a. "International Interdependence and
Integration," with Joseph S. Nye Jr. In Handbook of Political Science, ed. Nelson W. Polsby and Fred I. Greenstein. Reading, MA: Addison-Wesley.

1975b. "The Multinational Firm and International Regulation," with Van Doorn Ooms. International Organization 29(Winter).

$1975 \mathrm{c}$. "International Economics and International Politics: A Framework for Analysis," with C. Fred Bergsten and Joseph S. Nye Jr. International Organization 29(Winter)

1975d. "International Organization and the Crisis of Interdependence." International Organization 29(Spring).

1974a. "Transgovernmental Relations and International Organizations," with Joseph S. Nye Jr. World Politics 27(October).

1974b. "The Complex Politics of CanadianAmerican Interdependence," with Joseph S. Nye Jr. International Organization 28(Fall).

1973. "World Politics and the International Economic System," with Joseph S. Nye Jr. In The Future of the International Economic Order, ed. C. Fred Bergsten. Lexington, MA: Heath.

1972a. Transnational Relations and World Politics, edited with Joseph S. Nye Jr. Cambridge, MA: Harvard University Press.

1972b. "The Multinational Enterprise and World Political Economy." International Organization 26(Winter).

1972c. "The U.S. Multinational Enterprise and the Nation-State." Journal of Common Market Studies 11(September).

1971a. "The Big Influence of Small Allies." Foreign Policy, Spring.

1971b. "Coalition Theory and the Security Council: Some Notions About Institutional Change." In The United Nations: Problems and Prospects, ed. Edwin A. Pedder. St. Louis: Center for International Studies, University of Missouri.

1969a. "Institutionalization in the United $\mathrm{Na}$ tions General Assembly." International Organization 23(Fall).

1969b. "Lilliputians' Dilemmas: Small States in International Politics." Intemational Organization 23(Spring)

1969c. "Who Cares About the General Assembly?" International Organization 23(Winter)

1967. "The Study of Political Influence in the General Assembly." International Organization 21(Spring).

1966. "Political Influence in the General Assembly." International Conciliation 557(March).

\section{References}

Waltz, Kenneth Neal. 1979. Theory of International Politics. New York : Random House. 